\title{
The Molecularly Crowded Cytoplasm of Bacterial Cells: Dividing Cells Contrasted with Viable but Non-culturable (VBNC) Bacterial Cells
}

\author{
J. T. Trevors ${ }^{\star 1}$, J. D. van Elsas ${ }^{\star 2}$ and A.K. Bej ${ }^{\star 3}$ \\ ${ }^{1}$ Laboratory of Microbiology, School of Environmental \\ Sciences, University of Guelph, 50 Stone Rd. East, \\ Guelph, Ontario, N1G 2W1 Canada \\ ${ }^{2}$ Biological Center, University of Groningen, Kerklaan 30, \\ The Netherlands \\ ${ }^{3}$ College of Arts and Science, Dept. Biology, 464 Campbell \\ Hall, University of Alabama at Birmingham, AL 35294, USA
}

\begin{abstract}
In this perspective, we discuss the cytoplasm in actively growing bacterial cells contrasted with viable but nonculturable (VBNC) cells. Actively growing bacterial cells contain a more molecularly crowded and organized cytoplasm, and are capable of completing their cell cycle resulting in cell division. In contrast, nutrient starving bacteria in the physiological VBNC state are struggling to survive, as essential nutrients are not available or limiting. The cytoplasm is not as molecularly crowded as gene expression is minimal (e.g., ribosome, transcript, tRNA and protein numbers are decreased), energy pools are depleted, cells may exhibit leakage, and DNA is not being replicated for cell division.
\end{abstract}

\section{Introduction}

In this perspective, the molecularly crowded bacterial cytoplasm is discussed in growing/dividing cells compared to nutrient starved VBNC bacterial cells. There is still a paucity of knowledge on the profound changes in bacterial cytoplasm under different and often rapidly changing environmental conditions in diverse bacterial species. Even though the cytoplasm in bacterial cells is molecularly crowded and spatially organized, it is important to note that all matter (including soft matter living cells) is almost entirely empty space. All cells are made of atoms with 99.9 percent of the matter packed in the atomic nucleus (protons and neutrons with very similar masses; about $1.67 \times 10^{-24}$ $\mathrm{g})$. The remainder is space between the orbiting electrons and the nucleus. At the atomic level, living cells are 99.9 $\%$ space, while at the molecular level, the cytoplasm is densely packed with the molecules required for a living bacterial cell to metabolize and divide. The concept, definition or understanding of what empty is at the atomic level, and conversely what is crowded at the molecule level, with respect to living cells and organisms, has not been fully elucidated. A simple question can be posed, i.e., what is

*Corresponding authors:

jtrevors@uoguelph.ca; J.D.van.Elsas@biol.rug.nl; abej@uab.edu empty cytoplasmic space when discussing a living bacterial cell? Also, what is crowded in terms of the cytoplasm in a living bacterial cell?

The molecules, macromolecules, ions and metabolites in the bacterial cytoplasm (cytosol and all organelles and inclusions) of some species are mostly well-defined and understood (Ando and Skolnick, 2010; Braun et al., 2006. Cossins et al., 2011; Golding and Cox, 2006; Mika and Poolman 2011; Nenninger et al., 2010; Pollack et. al., 2009; Trevors, 2011a, 2012a; Vendeville et. al. 2010) (see Table 1 and Figure 1). However, there are numerous genes for which the corresponding proteins have not been elucidated and studied. In addition, molecule movement and specific localization (e.g., cell division proteins) in the cytoplasm still require a more profound understanding. The original perspective that the cytoplasm is a watery sac enclosed by a continuous, semipermeable, fluid, cytoplasmic membrane (living cell as a low entropy, open thermodynamic system) has been replaced with more profound knowledge of an organized and molecularly crowded cytoplasm, where protein localization and oscillations are advancing our knowledge on bacteria.

\section{The molecularly crowded and organized bacterial cytoplasm}

Cellular organization in bacteria is more controlled and less random than previously known (Kuthan, 2001; Vendeville et al., 2010). The bacterial cytoplasm is known to have a spatially variable composition depending on the stage of the cell cycle and nutrient status, with some subcellular compartmentalization (Lewis et. al., 2000). The bacterial cytoplasm may also contain numerous plasmids and bacteriophage structures. Large cytoplasmic polyanion macromolecules such as DNA and RNA have their large negative charges offset by an abundance of $\mathrm{K}^{+}$and $\mathrm{Mg}^{2+}$ ions (Cossins et. al. 2011).

The bacterial cytoplasm is maintained at a near neutral $\mathrm{pH}$ to permit an optimum cellular environment for biochemical reactions. Diffusion within the cytoplasm is considered to be the main mechanism of molecule movement. However, it has not been fully elucidated how proteins mobilize to specific cell locations (cell poles and mid-cell location) and oscillate during cell division. Smaller molecules in the cytoplasm are capable of faster diffusion. However they can be subjected to more non-specific random molecular interactions of no value to the cell's metabolism. Diffusion rates of different macromolecules in the cytoplasm of diverse bacterial species is an area where a paucity of knowledge exists. Molecular simulations of the entire cytoplasm under different environmental conditions and with different bacterial species are also lacking. The recent excellent simulation research on diffusion, crowding and protein stability in a dynamic molecular model of the 


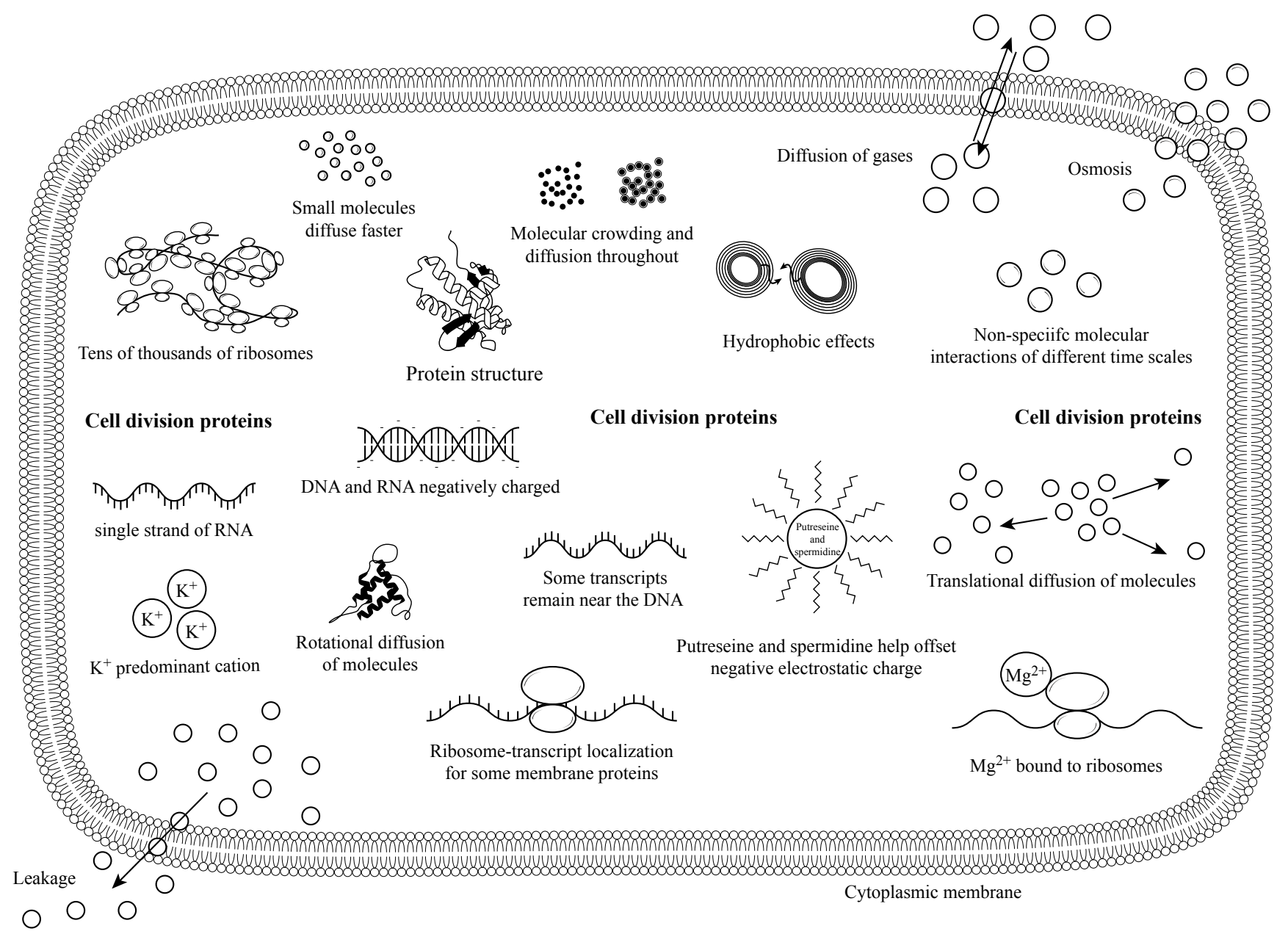

Figure 1: Organization and localization in the crowded cytoplasm of actively growing bacterial cells.

bacterial cytoplasm (McGuffee and Elcock, 2010) has made progress in this knowledge area.

The dynamic cytoplasm normally present in rapidly growing bacterial cells allows them to complete their cell cycles and divide (see Table 1 and Figure 1). A contrasting cytoplasmic state (see Table 2) is present in viable but nonculturable (VBNC) cells undergoing physiological starvation and stress, often due to limiting nutrients. During rapid cell growth and division, the cytoplasm will be more molecularly crowded and organized. However, during starvation survival, cell division proteins will be absent, DNA will not be replicating, gene expression will be minimal to nondetectable, and the ATP pool will be minimal. Cells may be dimensionally smaller and the cytoplasm will contain fewer molecules. It is noteworthy that a smaller cell size and fewer molecules may still result in some molecular crowding in the cytoplasm.

An estimate by Puesner (1974) reported 40,500,000,000 molecules in a single Escherichia coli cell. It was also estimated that 40,000,000,000 molecules were water. These water molecules would mainly be contained in the cytoplasm. Bacterial cells are the correct size for diffusion to be a central mechanism in the cytoplasm, that occupies about 20 to $50 \%$ of the cell volume (Zimmerman and Murphy, 1996). Bacterial cell sizes accommodate all the necessary biochemical pathways, cytoplasm, structured water, genetic instructions, proteins, ribosomes, lipids, carbohydrates, ions and structural components (e.g., cytoplasmic membrane, cell wall) for life. The cell is sufficiently large ( $\mu$ m dimension) to accommodate these required components but small enough for diffusion to be a mechanism sufficient for some of the cell's needs.

Some bacterial cells survive under suboptimal, stressed conditions (e.g., nutrient limitations, nutrient starvation, low temperature, high pressure, suboptimal $\mathrm{pH}$ ) and are designated VBNC. These cells cannot be grown/recovered (form colonies) on various laboratory growth media (Colwell, 2009; Oliver, 2005; Trevors, 2011b; van Overbeek et al., 1990). During physiological nutrient starvation in bacteria, carbohydrate molecules are depleted first, then proteins and some RNA. Loss or degradation of chromosomal DNA is more problematic as the cells may lose their capability to grow/divide. Bacterial cells in the VBNC state can become smaller and change from a rod 
Table 1: Some features of the bacterial cytoplasm (cytosol and all organelles and inclusions).

- Structured and organized gel, not a watery sac enclosed by a cytoplasmic membrane.

- Contains salts, ions, sugars, amino acids, macromolecules, vitamins, coenzymes and about 2000 different proteins.

- About 200-300 mg/ml protein (Keighron and Keating, 2011).

- Spatially varied composition with some compartmentation.

Cytoplasm contains all nucleic acids.

- Largest single structure in the cytoplasm is the chromosome

DNA is condensed (concentrated state occupying a fraction of the cytoplasm).

Cytoplasm occupies about $1 / 2$ to 1/5 of cell volume (Zimmerman and Murphy, 1996).

May contain plasmids and viruses.

- Contains large number of negatively charged molecules (DNA, RNA).

Electro-neutrality is maintained by large concentration of potassium ions.

- Putreseine and spermidine assist in offsetting negative electrostatic charges.

- Electrostatics is a dominant force.

Diffusion is also dominant (e.g., rotational and translational).

Hydrophobic effects.

- Variable gene expression depending on the environmental conditions.

Small molecules can diffuse faster.

Cell division can involve cell polarity and protein oscillations.

Tens of thousands of ribosomes.

Ribosome-transcript localization for some membrane protein synthesis

Some cell division proteins localized at the mid-cell location.

- Non-specific molecular interactions over different time scales.

- Cells in a viable but-nonculturable (VBNC) state may have less molecular crowding.

- ATP pool is variable depending on metabolic activities.

- Leakage can occur (e.g., $\mathrm{K}^{+}$, amino acids) from cytoplasm to external environment.

- Internal cytoplasmic $\mathrm{pH}$ is near neutral.

to a spherical shape (Clements and Foster, 1998). The chromosomal DNA can be compressed and surrounded by dense cytoplasm, which has a protective effect on the DNA. Cell death is often the outcome for many of the cells. Recovery from starvation occurs when the stress conditions are removed and conditions become more optimal for growth. RNA synthesis occurs first, followed by protein synthesis, increased cell size, DNA replication and finally cell division if the environmental conditions are favourable (Colwell, 2009; Trevors, 2011b, 2012b; Clements and Foster, 1998; Nyström, 2003; Oliver, 2005). (see Table 2).

The normal molecularly crowded and somewhat organized bacterial cytoplasm is illustrated in Figure 1 and also described in Table 1. The protein concentration can be in the $200-300 \mathrm{mg} / \mathrm{ml}$ magnitude, the circular chromosome can be replicated and is the largest single structure or macromolecule. In some bacterial cells the cytoplasm may experience additional crowding because of the presence of different plasmids with different copy numbers, and viral particles being replicated and assembled. The presence of plasmids and assembled bacteriophage particles adds to the molecular crowding in the cytoplasm. The negative charges on DNA and RNA are offset by $\mathrm{K}^{+}$as the predominant intracellular ion, $\mathrm{Mg}^{2+}$ and the presence of putrescine and spermidine. Diffusion within the cytoplasm is also considered to be the dominant mechanism for movement 
Table 2. Comparison of cytoplasm in actively growing/dividing bacterial cells to VBNC cells.

\begin{tabular}{|l|l|}
\hline Actively growing/dividing & VBNC physiological state \\
\hline Molecularly crowded cytoplasm & Less molecular crowding \\
\hline Optimal diffusion & Minimal diffusion \\
\hline Higher total protein concentration & Lower total protein concentration \\
\hline $\begin{array}{l}\text { More organization of molecules such as } \\
\text { cell division proteins }\end{array}$ & $\begin{array}{l}\text { Less molecular organization such as cell } \\
\text { division proteins }\end{array}$ \\
\hline Optimal protein oscillations & Fewer to no protein oscillations \\
\hline High ribosome numbers & Fewer ribosomes \\
\hline Optimal gene expression & Minimal to no gene expression \\
\hline Higher number of transcripts & Minimal transcripts \\
\hline High tRNA content & Minimal tRNA \\
\hline Optimal cytoplasmic membrane fluidity & $\begin{array}{l}\text { Cytoplasmic membrane may be less fluid } \\
\text { with leakage from cytoplasm (e.g., } \mathrm{K}^{+} \text {) }\end{array}$ \\
\hline Optimal ATP pool & Minimal ATP pool \\
\hline More nonspecific molecule interactions & Fewer nonspecific molecule interactions \\
\hline $\begin{array}{l}\text { Optimal cytoplasm volume just before cell } \\
\text { division }\end{array}$ & Minimal cytoplasm volume \\
\hline Replicating DNA & Condensed DNA \\
\hline Optimal Mg ${ }^{2+}$ & Less Mg ${ }^{2+}$ \\
\hline
\end{tabular}

of molecules. Smaller molecules can diffuse faster and may have more non-specific interactions. Gene expression (combined transcription and translation) can change quickly in response to often rapidly changing environmental conditions. Different cell division proteins occupy the midcell location as well as the polar ends, of some cells. Of special significance in VBNC cells will be depleted ATP pools because of minimal biochemical metabolism.

For example, Vibrio spp. have been researched for their VBNC state and their significant pathology effects (Brauns et al., 1991; Wai et al., 1999). Vibrio cholerae, the causal agent of diarrheal cholera is a profound, worldwide, public health challenge, especially where potable water infrastructure and sewage treatment are lacking (Wai et al., 1999). This bacterium responds to environmental stresses by becoming coccoid, simultaneously decreasing its cell volume. The nuclear region in the cytoplasm becomes dense. The total cellular lipid, carbohydrate and PHB (poly$\beta$-hydroxybutrate) decreases, suggesting these molecules are being consumed during starvation survival. The RNA, DNA and protein content also decreases. The decrease in DNA content is noteworthy as the genetic instructions are required for subsequent cell growth and division (Trevors, 2011b).

Less is known about the changes in bacterial cytoplasm, and how quickly these changes occur, during starvation survival. However, because the cells are not replicating their DNA and cell division is not occurring, many features of the cytoplasm can be hypothesized and deduced as the VBNC state has a profound effect on cells. For example, a comparison of cytoplasm in actively growing/dividing bacterial cells compared to VBNC cells is presented in Table 2. The cytoplasm of the intact VBNC cells will have less molecular crowding, minimal diffusion, less molecular organization such as oscillating polar cell division proteins and the mid-cell division protein. The cytoplasm will typically have lower total protein, RNA and carbohydrate concentrations. Ribosome numbers will be minimal and there will be minimal, to no gene expression. In addition, the ATP pool within the cell will be decreased. There will be a minimal cytoplasmic volume, as the cells are not preparing for DNA replication and cell division. Moreover, ions such as $\mathrm{K}^{+}$and $\mathrm{Mg}^{2+}$ can be leaked from the cytoplasm if the cytoplasmic membrane integrity has been breached or the 
membrane has undergone a phase transition to a more rigid, or less fluid state (Denich et. al. 2003a,b; Mykytczuk et al., 2007; Trevors, 1983; 2003). The cytoplasmic dynamics of VBNC cells is profoundly different from that of growing and dividing cells at the molecular level of organization. The capability for some bacterial cells to survive in this state without the need to produce resistant spores provides a significant evolutionary advantage, when the environmental conditions become more conducive for the cells to again be able to divide. From an evolutionary perspective, the first bacterial cells would have faced numerous stressful or suboptimal conditions. The capability for the cytoplasm contents to be altered, and for cells to remain viable could have been a central component of the evolution of the first bacterial cells.

\section{Future outlook}

Future research in biophysics, cell and molecularbacteriology will bring forth new knowledge on the cytoplasmic molecular crowding and localization in different bacterial species under diverse and often dynamic environmental conditions. Some of this knowledge will be obtained from bacteria grown under optimal conditions while other data will arise from cells grown under suboptimal and even extreme conditions such as nutrient starvation (e.g., cells incubated in sterile distilled water). Additional knowledge will be required on protein localization and rapid protein oscillations during cell division, and transcript mobilization and arrival at specific ribosome locations in the cytoplasm. Real-time single cell image analysis will be useful as research on macromolecular behavior in vivo are undertaken in real-time (Trevors, 2010). Specific molecular interactions also occur against the background of random molecular interactions, which can affect diffusion, protein folding and localization in bacterial cells. However, a better understanding is emerging of the organized bacterial cytoplasm that can change over short periods of time such as during growth and cell division.

Additional research will include imaging analysis, molecular models of the cytoplasm, gene expression studies under different environmental conditions, protein oscillations during cell division and mobilization of macromolecules to specific cellular sub-locations and the mechanisms responsible. The knowledge forthcoming will be significant in medical, industrial, basic and applied/ environmental microbiology.

\section{Acknowledgements}

Research by J.T.T. is supported by the Discovery Program of NSERC (Canada).

\section{References}

Ando, T. and J. Skolnick. 2010. Crowding and hydrodynamic interactions likely dominate in vivo macromolecular motion. PNAS. 10:18457-184562.

Braun, F. N., W. P. Krekelberg and T. M. Truskett. 2006. Volatile diffusional character of cytoplasm. J Phys. Chem. B Letts. 110:25606-25607.

Clements M. O. and S. J. Foster. 1998. Starvation recovery of Staphylococcus aureus 8325-8334. Microbiol. 144:1755-1763.

Colwell RR. (2009) Viable but not cultivable bacteria. Microbiol. Monogr. Doi:10.1007/7171_2009_1
Cossins, B. P., M. P. Jacobsen and V. Guallar. 2011. A new view of the bacterial cytosol environment. PLoS 7(6) e10002066.

Denich, T. J., H. Lee and J. T. Trevors. 2003a. Effect of selected environmental and physico-chemical factors on bacterial cytoplasmic membranes. J. Microbiol. Meths. 52:149-182.

Denich, T. J., L. A. Beaudette, M. B. Cassidy, H. Lee and J. T. Trevors. 2003b. Membrane fluidity of the pentachlorophenol- mineralizing Sphingomonas sp. UG30. Journal of Fluorescence. 13: 385-391.

Golding, I. and E. C. Cox. 2006. Physical nature of bacterial cytoplasm. Phys. Rev. Letts. 96: 098102.

Kreighron, J. D. and C. D. Ketaing. 2011. Towards a minimal cytoplasm. In The Minimal Cell: The Biophysics of Cell Compartment and the Origin of Cell Functionality. (Eds. P. L. Luisi and P. Stano), pp. 3-30, Springer.

Kuthan, H. 2001. Self-organization and orderly processes by individual protein complexes in the bacterial cell. Prog. Biophys. Mol. Biol. 75:1-17.

Lewis, P. J., S. D. Thaker and J. Errington. 2000. Compartmentalization of transcription and translation in Bacillus subtilus. EMBO J. 19:710-718.

Mykytczuk, N., J. T. Trevors, G. Ferroni and L. Leduc. 2007. Fluorescence polarization in studies of bacterial cytoplasmic membrane fluidity under environmental stress. Prog. Biophys. Mol. Biol. 95:60-82.

McGuffee, S. R. and A. H. Elcock. 2010. Diffusion, crowding and protein stability in a dynamic molecular model of the bacterial cytoplasm. PLoS Computational Biol. 6(3) e1000694.

Mika, J. T. and B. Poolman. 2011. Macromolecule diffusion and confinement in prokaryotic cells. Curr. Opin. Biotechnol. 22: 117-126.

Nenninger, A., G. Mastroiannia nd C. W. Mullineaux. 2010. Size dependence of protein diffusion in the cytoplasm of Escherichia coli. J. Bacteriol. 192: 4535-4540.

Nyström T. 2003. Nonculturable bacteria: programmed survival forms or cells at death's door. BioEssays 25: 204211.

Oliver, J.D. 2005. The viable but nonculturable state in bacteria. J. Microbiol. Spec. No. 43:93-100.

Pilhofer, M., M. Pavlekovic, N.M. Lee, W. Ludwig and K.H. Schleifer. 2009. Fluorescence in situ hybridization for intracellular localization of nifH mRNA. Sys. Appl. Microbiol. 32: 186-192.

Pollack, G. H., X. Figueroa and Q. Zhang. 2011. The minimal cells and life's origin: role of water and aqueous interfaces. In P. L. Luisi and P. Stano (eds.) The Minimal Cell: The Biophysics of Cell Compartment and the Origin of Cell Functionality, Springer, pp. 105-121.

Puesner, L. 1974. Concepts in Bioenergetics. Prentice-hall, Englewood Cliffs, New Jersey, USA.

Trevors, J.T. 1983. Effect of pentachlorophenol on the membrane fluidity of Pseudomonas fluorescens. FEMS Microbiology Letters 16: 331-334.

Trevors, J. T. 2003. Fluorescent probes for bacterial cytoplasmic membrane research. J. Biochem. Biohys. Meths. 1693:1-18.

Trevors, J. T. 2010. Perspective: time scales in scientific research: microbial cellular and molecular research. J. Microbiol. Meths. 82:102-107. 
6 Trevors et al.

Trevors, J. T. 2011a. The composition and organization of cytoplasm in prebiotic cells. Int. J. Mol. Sci. 12:1650-1659.

Trevors, J. T. 2011b. Viable but non-culturable (VBNC) bacteria: gene expression in planktonic and biofilm cells. J. Microbiol. Meths.86:266-273.

Trevors, J. T. 2012a. A perspective on the biochemical and physical nature of bacterial cytoplasm: mobilization and delivery of molecules. Curr. Issues Mol. Biol. 14: 38-46.

Trevors, J. T. 2012b. Can dead bacterial cells be defined and are genes expressed after cell death? J. Microbiol. Meths. (in press).

van Overbeek, L.S., J.D. van Elsas, J.T. Trevors and M.E. Starodub. 1990. Long-term survival of Pseudomonas and
Klebsiella spp. and appearance of nonculturable cells in agricultural drainage water and plasmid stability in water. Microbiol. Ecol. 19: 239-249.

Vendeville, A., D. Lariviere and E. Fourmentin, 2010. An inventory of the bacterial macromolecular components and their spatial organization. FEMS Microbiol. Rev. xx:120. DOI: 10.1111/j.1574-6976.2010.00254.x

Zimmerman, S. B. and L. D. Murphy. 1996. Macromolecular crowding and the mandatory condensation of DNA in bacteria. FEBS Letts. 390(3): 245-248. 


\section{Further Reading}

Caister Academic Press is a leading academic publisher of advanced texts in microbiology, molecular biology and medical research. Full details of all our publications at caister.com

- MALDI-TOF Mass Spectrometry in Microbiology Edited by: M Kostrzewa, S Schubert (2016) www.caister.com/malditof

- Aspergillus and Penicillium in the Post-genomic Era Edited by: RP Vries, IB Gelber, MR Andersen (2016) www.caister.com/aspergillus2

- The Bacteriocins: Current Knowledge and Future Prospects Edited by: RL Dorit, SM Roy, MA Riley (2016)

www.caister.com/bacteriocins

- Omics in Plant Disease Resistance Edited by: V Bhadauria (2016) www.caister.com/opd

- Acidophiles: Life in Extremely Acidic Environments Edited by: R Quatrini, DB Johnson (2016) www.caister.com/acidophiles

- Climate Change and Microbial Ecology: Current Research and Future Trend

Edited by: J Marxsen (2016)

www.caister.com/climate

- Biofilms in Bioremediation: Current Research and Emerging Technologies

Edited by: G Lear (2016)

www.caister.com/biorem

- Microalgae: Current Research and Applications Edited by: MN Tsaloglou (2016) www.caister.com/microalgae

- Gas Plasma Sterilization in Microbiology: Theory, Applications, Pitfalls and New Perspectives Edited by: H Shintani, A Sakudo (2016) www.caister.com/gasplasma

- Virus Evolution: Current Research and Future Directions Edited by: SC Weaver, M Denison, M Roossinck, et al. (2016) www.caister.com/virusevol

- Arboviruses: Molecular Biology, Evolution and Control Edited by: N Vasilakis, DJ Gubler (2016) www.caister.com/arbo

- Shigella: Molecular and Cellular Biology Edited by: WD Picking, WL Picking (2016) www.caister.com/shigella

-Aquatic Biofilms: Ecology, Water Quality and Wastewater Treatment

Edited by: AM Romaní, H Guasch, MD Balaguer (2016)

www.caister.com/aquaticbiofilms

- Alphaviruses: Current Biology

Edited by: S Mahalingam, L Herrero, B Herring (2016)

www.caister.com/alpha

- Thermophilic Microorganisms

Edited by: F Li (2015)

www.caister.com/thermophile
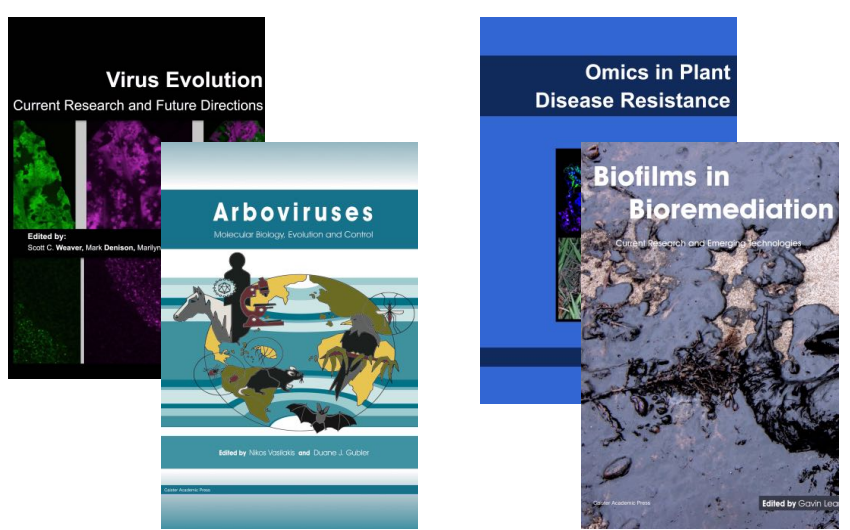
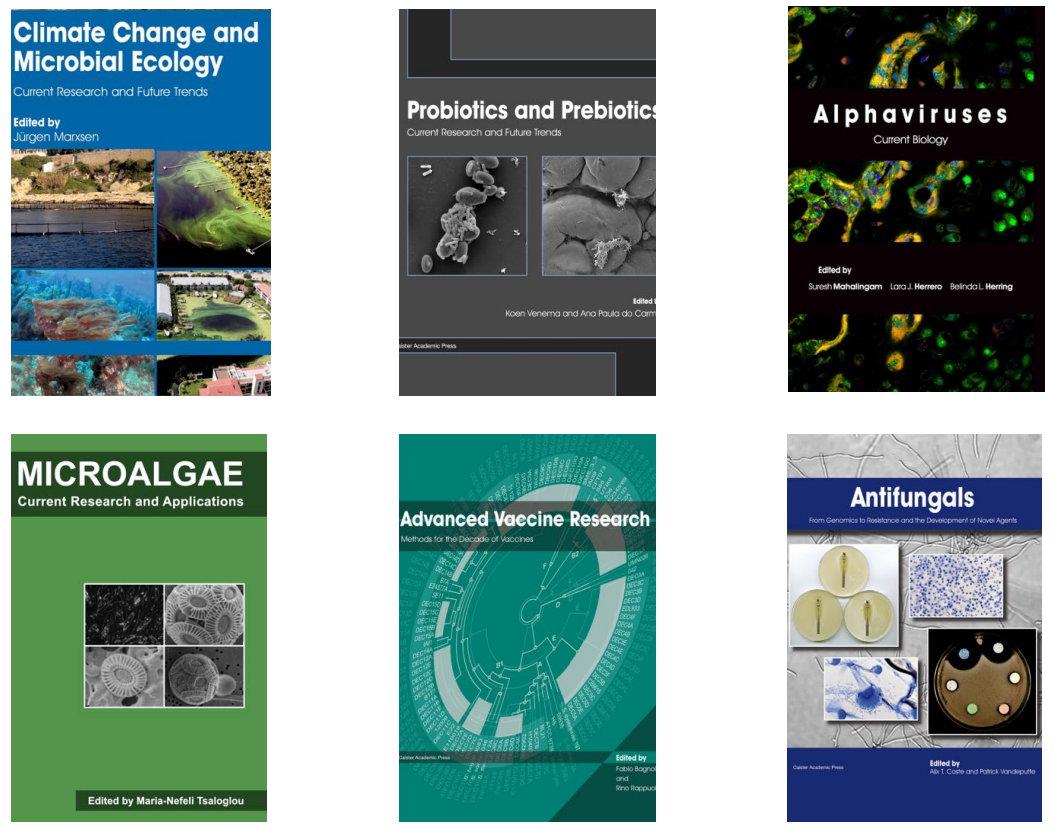

- Flow Cytometry in Microbiology: Technology and Applications Edited by: MG Wilkinson (2015) www.caister.com/flow

- Probiotics and Prebiotics: Current Research and Future Trends Edited by: K Venema, AP Carmo (2015) www.caister.com/probiotics

- Epigenetics: Current Research and Emerging Trends Edited by: BP Chadwick (2015) www.caister.com/epigenetics2015

- Corynebacterium glutamicum: From Systems Biology to Biotechnological Applications

Edited by: A Burkovski (2015)

www.caister.com/cory2

- Advanced Vaccine Research Methods for the Decade of Vaccines

Edited by: F Bagnoli, R Rappuoli (2015)

www.caister.com/vaccines

- Antifungals: From Genomics to Resistance and the Development of Novel Agents

Edited by: AT Coste, P Vandeputte (2015)

www.caister.com/antifungals

- Bacteria-Plant Interactions: Advanced Research and Future Trends Edited by: J Murillo, BA Vinatzer, RW Jackson, et al. (2015) www.caister.com/bacteria-plant

\section{- Aeromonas}

Edited by: J Graf (2015)

www.caister.com/aeromonas

- Antibiotics: Current Innovations and Future Trends

Edited by: S Sánchez, AL Demain (2015)

www.caister.com/antibiotics

- Leishmania: Current Biology and Contro Edited by: S Adak, R Datta (2015) www.caister.com/leish2

- Acanthamoeba: Biology and Pathogenesis (2nd edition) Author: NA Khan (2015)

www.caister.com/acanthamoeba2

- Microarrays: Current Technology, Innovations and Applications Edited by: Z He (2014)

www.caister.com/microarrays2

- Metagenomics of the Microbial Nitrogen Cycle: Theory, Methods and Applications

Edited by: D Marco (2014)

www.caister.com/n2 